\title{
Occurrence, structure, biochemical properties and technological characteristics of lactoferrin
}

\author{
Jan M. Steijns* and A. C. M. van Hooijdonk \\ DMV International, R\&D Center, PO Box 13, 5460 BA Veghel, The Netherlands
}

\begin{abstract}
The structure of the iron-binding glycoprotein lactoferrin, present in milk and other exocrine secretions, has been elucidated in great detail, both the three-dimensional protein structure and the attached N-glycans. Structure-function relationships are being established. From these studies a function for lactoferrin in host defence and modulation of iron metabolism emerges. This paper describes in some detail how iron and other cations may be bound by lactoferrins from human or bovine sources and elucidates parts of the molecule that are critical for interactions with cells and biomolecules. Furthermore, the technological aspects, more specifically the heat-sensitivity, of bovine lactoferrin in different matrices are described.
\end{abstract}

\section{Lactoferrin: Occurrence: Properties: Application}

\section{Background}

Lactoferrin, an iron-binding glycoprotein of the transferrin family, has attracted increasing scientific interest since the early 1960s due to its high concentration in human breast milk (Lönnerdal \& Iyer, 1995). The molecule has been identified in a number of mammalian species, like the cow, pig, equine, buffalo, goat and mouse. Many studies have been undertaken to pinpoint the biological role(s) of lactoferrin (Reiter, 1985; Sanchez et al. 1992a; Hambraeus \& Lönnerdal, 1994). To date four conferences have been devoted to unravelling the features of its structure and establishing the structurefunction relationships of this versatile and intriguing molecule (Hutchens et al. 1994; Hutchens \& Lönnerdal, 1997; Spik et al. 1998; Shimazaki et al. 2000). Not surprisingly its functionality is related to the strong ironbinding properties, but non-iron related activities have also been described. Table 1 summarizes the various reported activities. Although its role in breast milk is still debated, it is evident from Table 1 that lactoferrin is a potential functional food ingredient for optimal dietary provision with iron and stimulation of the intestinal host defence.

This paper gives an overview of the occurrence, structure, biochemical properties and technological characteristics of lactoferrin. It focuses on bovine lactoferrin because of its similarity in structure and function to human lactoferrin and its commercial availability in metric ton amounts, thus allowing its application in infant formulas, foods, nutritional supplements or medical care. Where appropriate a comparison is made to native or recombinant human lactoferrin.

\section{Occurrence}

Lactoferrin is predominantly found in the products of the exocrine glands located in the gateways of the digestive, respiratory and reproductive systems, suggesting a role in the non-specific defence against invading pathogens. Thus one may not only find lactoferrin in the milk secreted by the mammary gland, providing protection to the neonate, but also in tears, synovial fluids, saliva and seminal fluid. Table 2 shows a selection of the lactoferrin amounts reported from these various biological fluids. Lactoferrin may also be found in blood. Plasma lactoferrin is derived from the neutrophils, which degranulate and synthesize lactoferrin during inflammation (Britigan et al. 1994; Levay \& Viljoen, 1995). By means of immunohistochemistry, Inoue et al. (1993) demonstrated the presence of bovine lactoferrin in a variety of exocrine glands. Their observations support the idea that lactoferrin may have an antibacterial role.

Studies by Schanbacher et al. (1997) reveal that lactoferrin concentrations change during the mammary cycle. In the cow the concentrations of lactoferrin and its messenger RNA especially increase during development of the mammary gland, colostrum formation and involution of the gland, whereas during lactation the levels of lactoferrin decrease, as opposed to the increasing levels of casein. The latter suggests that casein has primarily a nutritional function for the calf, whereas lactoferrin may have growth factor-like activity and protective functions for the (non-) lactating gland and the critical phase for the newborn just after birth.

\footnotetext{
* Corresponding author: Dr. Jan Steijns, DMV International, Center of Expertise for Nutrition, PO Box 14, 6700 AA Wageningen, The Netherlands, fax +31317475 769; email steijnsj@dmv-international.com
} 
Table 1. Reported in vitro and in vivo activities of lactoferrin

\begin{tabular}{|c|c|c|}
\hline Activity & Mechanism & References \\
\hline Iron absorption & Increasing solubility and receptor mediated uptake & Kawakami et al. 1988, 1993; Mikogami et al. 1995 \\
\hline Antioxidant & Iron scavenger & Matsue et al. 1994, 1995 \\
\hline Antimicrobial & $\begin{array}{l}\text { Growth inhibition by iron scavenging or membrane } \\
\text { desintegration }\end{array}$ & Reiter, 1985; Naidu \& Arnold, 1997 \\
\hline Antiviral & Prevention of virus attachment & Harmsen et al. 1995; Marchetti et al. 1996; Yi et al. 1997 \\
\hline $\begin{array}{l}\text { Anti-inflammatory, } \\
\text { immune modulating }\end{array}$ & $\begin{array}{l}\text { LPS binding, stimulation of NK cells, reduction of } \\
\text { pro-inflammatory cytokines, T-cell maturation }\end{array}$ & $\begin{array}{l}\text { Zimecki et al. 1991; Cohen et al. 1992; Mattsby-Baltzer } \\
\text { et al. 1996; Shimizu et al. } 1996\end{array}$ \\
\hline Anti-cancer & Unknown & Bezault et al. 1994; Sekine et al. 1997; Yoo et al. 1997 \\
\hline
\end{tabular}

\section{Structure}

Lactoferrins are single chain polypeptides of about $80000 \mathrm{Da}$ containing 1-4 glycans, depending on the species (Spik et al. 1994). Bovine and human lactoferrin consist of 689 and 691 amino acids, respectively; the sequence identity is $69 \%$ (Pierce et al. 1991). The 3-D conformations of both human and bovine lactoferrin are now known in great detail due to the pioneering work of Baker and colleagues (Haridas et al. 1995; Moore et al. 1997). The elucidation of the structure of the glycans attached to lactoferrins from various species has been the result of the extensive studies of Montreuil, Spik and coworkers (Coddeville et al. 1992; Spik et al. 1994).

The 3-D structures of bovine and human lactoferrin are very similar, but not identical. Each lactoferrin comprises two homologous lobes, called the $\mathrm{N}$ - and C-lobes, referring to the $\mathrm{N}$-terminal and $\mathrm{C}$-terminal part of the molecule, respectively. Each lobe further consists of two sub-lobes or domains, which form a cleft where the ferric ion $\left(\mathrm{Fe}^{3+}\right)$ is tightly bound in synergistic cooperation with a (bi)carbonate anion. These domains are called N1, N2, C1 and C2, respectively. In bovine lactoferrin $\mathrm{N} 1$ stands for the sequences 1-90 and 251-233, N2 for 91-250, C1 for 345-431 and 593-676, and C2 for 432-592; the sequence 334-344 represents the so-called hinge, which is a helix conformation with three turns and fulfils a role during opening and closing of the domains. The secondary structure is partly due to the presence of disulphide bridges between cysteine residues. The amino acids contributing to the binding of ferric ions in the cleft are Asp60, Tyr92, Tyr192 and His253 in the N-lobe and Asp395, Tyr433, Tyr526 and His595 in the C-lobe; in both lobes the (bi)carbonate ion acts synergistically in the iron binding. The reader is referred to the papers of Moore et al. (1997) and Haridas et al. (1995) for more structural details.

Table 2. Occurrence of lactoferrin in biological fluids

\begin{tabular}{ll}
\hline Biological fluid & Amounts reported \\
\hline Colostral breast milk & $>7 \mathrm{mg} / \mathrm{ml}$ \\
Mature breast milk & $>1-2 \mathrm{mg} / \mathrm{ml}$ \\
Tear fluid & $>2.2 \mathrm{mg} / \mathrm{ml}$ \\
Seminal plasma & $>0.4-1.9 \mathrm{mg} / \mathrm{ml}$ \\
Synovial fluid & $>10-80 \mu \mathrm{g} / \mathrm{ml}$ \\
Saliva & $>7-10 \mu \mathrm{gl}$ \\
Cow's colostral whey & $>1.5 \mathrm{mg} / \mathrm{ml}$ \\
Cow's milk & $>20-200 \mu \mathrm{g} / \mathrm{ml}$ \\
\hline
\end{tabular}

* Data taken from: Korhonen, 1977; Arnold et al. 1979; Renner et al. 1989; Levay \& Viljoen, 1995.
In bovine lactoferrin there are five potential sites for $\mathrm{N}$ bound glycan structures: the asparagine (Asn) residues at positions 233, 281, 368, 476 and 545. The chemical analysis, however, only reveals four N-linked glycans; apparently Asn281 is not used. The residue Asn476 seems to be conserved among species. Spik et al. (1994) gives a nice overview on the glycans attached to lactoferrins of different species and further illustrates the complexity of these structures. The sugars found in bovine lactoferrin are $\mathrm{N}$-acetyllactosamine, $\mathrm{N}$-acetylglucosamine, galactose, fucose, mannose and neuraminic acid.

\section{Biochemical properties}

\section{Iron binding}

In the 'natural state' bovine lactoferrin is only partly saturated with iron (15-20\%) and has a salmon pink colour, the intensity of which depends on the degree of iron saturation. Iron-depleted lactoferrin with less than $5 \%$ iron saturation is called apolactoferrin, whereas iron-saturated lactoferrin is referred to as hololactoferrin. In breast milk the lactoferrin found is essentially apolactoferrin.

The affinity of lactoferrin for iron is very high (about 260 times that of blood serum transferrin) with an affinity constant of about $10^{20}$ (Baker et al. 1994). The iron-binding capacity of lactoferrin is dependent on the presence of (small amounts) of (bi)carbonate. The binding site appears to be optimized for the binding of ferric iron and (bi)carbonate with respect to size, charge and stereochemistry, as evidenced from a number of structural studies with different anions and cations, or using mutant recombinant lactoferrins (Harrington et al. 1987; Baker et al. 1994; Brodie et al. 1994; Faber et al. 1997). Oxalate can replace (bi)carbonate with regard to iron binding, but citrate can not. However, citrate may bind to bovine lactoferrin during isolation (Brodie et al. 1994), which reflects the in vivo situation in the milk. Depending on the bicarbonate concentration, high concentrations of citrate can counteract the iron-binding efficiency of lactoferrin (Reiter, 1985).

Cations other than ferric iron may be bound in the cleft and change the wavelength absorption maximum; e.g. ferric iron-saturated lactoferrin has an absorption maximum at $466 \mathrm{~nm}$, whereas copper $\left(\mathrm{Cu}^{2+}\right)$-saturated lactoferrin has a maximum at $434 \mathrm{~nm}$ (Brodie et al. 1994). Besides $\mathrm{Cu}^{2+}$, $\mathrm{Mn}^{3+}, \mathrm{Co}^{3+}, \mathrm{Zn}^{2+}$ may also be bound.

Using site-directed mutagenesis Ward et al. (1996) purified mutant $\mathrm{C}$ - and N-lobe human lactoferrins from Aspergillus awamori; in these lactoferrins the two tyrosine residues involved in the iron binding were changed for 
Table 3. Number of amino acid residues in bovine and human lactoferrin (Pierce et al. 1991)

\begin{tabular}{lrr}
\hline & Bovine milk & Human milk \\
\hline Alanine & 67 & 63 \\
Proline & 30 & 35 \\
Arginine & 39 & 43 \\
Lysine & 54 & 46 \\
Asparagine & 29 & 33 \\
Valine & 47 & 48 \\
Tryptophan & 13 & 10 \\
Cysteine & 34 & 32 \\
Threonine & 36 & 31 \\
Isoleucine & 15 & 16 \\
Serine & 45 & 50 \\
Glutamine & 29 & 27 \\
Glutamic acid & 40 & 42 \\
Phenylalanine & 27 & 30 \\
Methionine & 4 & 5 \\
Leucine & 65 & 58 \\
Glycine & 48 & 54 \\
Tyrosine & 22 & 21 \\
Aspartic acid & 36 & 38 \\
Histidine & 9 & 9 \\
Total number of residues & 689 & 691 \\
\hline
\end{tabular}

alanine either in the $\mathrm{C}$-lobe or the $\mathrm{N}$-lobe or both. Their studies suggest that the $\mathrm{C}$-lobe contributes more to iron stabilization than the N-lobe.

Legrand et al. (1990) studied the iron binding site of the $\mathrm{N}$-lobe of both native human and bovine lactoferrins using the $30 \mathrm{kDa}$ tryptic fragment N4-281 (including domains N1 and N2) and the $20 \mathrm{kDa}$ tryptic fragment N91-251 (domain N2). From their $\mathrm{pH}$-induced iron release studies they concluded that the absence of the Asp60 residue from domain N2 did not influence the iron stability. Furthermore, they also found evidence for iron stabilizing interactions between the $\mathrm{N}$-lobe (30 $\mathrm{kDa}$ tryptic fragment) and the C-lobe (a $50 \mathrm{kDa}$ tryptic fragment). Bovine lactoferrin started to release iron when the $\mathrm{pH}$ was below 4, whereas human lactoferrin was somewhat more resistant with release below $\mathrm{pH} 3$. Finally they showed that full deglycosylation of both tryptic N-lobe fragments led to 50$100 \%$ loss of the iron-binding capacity. Studies on intact deglycosylated recombinant human lactoferrin, however, did not show a decrease in iron binding (VanBerkel et al. 1995).

\section{Physico-chemical properties}

The amino acid compositions of bovine and human lactoferrin are shown in Table 3.

Lactoferrin has a very high isoelectric point. The theoretical pI values calculated for bovine and human lactoferrin are 9.4 and 9.5 , respectively; yet, reported experimental values may deviate a lot (Shimazaki et al. 1993). Depending on the method used values around 8 have been reported for bovine lactoferrin, whereas a wide range of pI $5 \cdot 5$ to 10 have been reported for human lactoferrin. This variation may be due to variations in the arginine rich $\mathrm{N}$-terminus of the molecule due to separation conditions (VanBerkel, 1998).

Electrophoretic comparisons between lactoferrins from bovine mammary secretions, milk neutrophils and human milk have been published by Hurley et al. (1993). These authors found differences in mobility in SDS-PAGE gels between neutrophil-derived lactoferrin and mammary gland-secreted lactoferrin; the latter migrated with an apparent molecular weight of about $4 \mathrm{kDa}$ lower. Human milk lactoferrin also separated as two distinct bands in the gels. All tested lactoferrins were glycosylated; differences in relative lectin-binding properties were observed between human and bovine milk lactoferrin.

Magnusson et al. (1990) demonstrated evidence for shared antigenic determinants among human, bovine and pig lactoferrin.

\section{Strong cationic N-terminus}

The N-terminus of both human and bovine lactoferrin has strong cationic peptide regions that are responsible for a number of important binding characteristics.

The binding of bacterial LPS (lipopolysaccharide) involves a loop in the N1 domain of both human and bovine lactoferrin which expresses a high affinity binding site; the C-lobe appears to have low affinity binding sites (100-130 times lower affinity). The human loop apparently consists of the sequence 28-34; the bovine loop resides in the sequence 17-41 (Elass-Rochard et al. 1995).

VanBerkel et al. (1997) studied the binding of human lactoferrin to lysozyme, LPS, heparin and DNA with intact and N-terminally deleted lactoferrin molecules. They showed that the degree of iron saturation does not influence the binding to all these four compounds. But removal of one or more arginine residues ( $\mathrm{Arg}^{2}, \mathrm{Arg}^{3}, \mathrm{Arg}^{4}, \mathrm{Arg}^{5}$ ) decreased the binding of lactoferrin to different extents and the more upon removal of extra arginine residues. No binding occurred with a mutant lactoferrin that had lost the first five amino acid residues $\left(\mathrm{Gly}^{1}-\mathrm{Arg}^{2}-\mathrm{Arg}^{3}-\mathrm{Arg}^{4}-\mathrm{Arg}^{5}\right)$. This demonstrates the decisive role that this stretch of four arginine residues in interaction with biomolecules plays in host defence.

Legrand et al. (1997) were able to demonstrate that the number of binding sites of human lactoferrin for human lymphoblast T-cells was highest for the intact molecule, but decreased progressively from about 100000 per cell to 17000 per cell upon removal of, respectively, $\mathrm{Arg}^{2}, \mathrm{Arg}^{3}$ and $\mathrm{Arg}^{4}$. Bovine lactoferrin had about the same binding parameters as intact human lactoferrin. These authors propose that the binding occurs to the sulphated molecules on the cells and that the $\mathrm{Arg}^{5}$ residue does not play a role in this respect.

The cationic N-terminus of bovine lactoferrin is of special interest because of the reported antibacterial activity (Bellamy et al. 1992; Tomita et al. 1994; Kang et al. 1996; Dionysius \& Milne, 1997; Hoek et al. 1997). This aspect will be dealt with in greater detail by van Hooijdonk \& Steijns in part B of this supplement.

\section{Technological characteristics}

\section{Heat stability}

The thermal stability of lactoferrin has predominantly been 


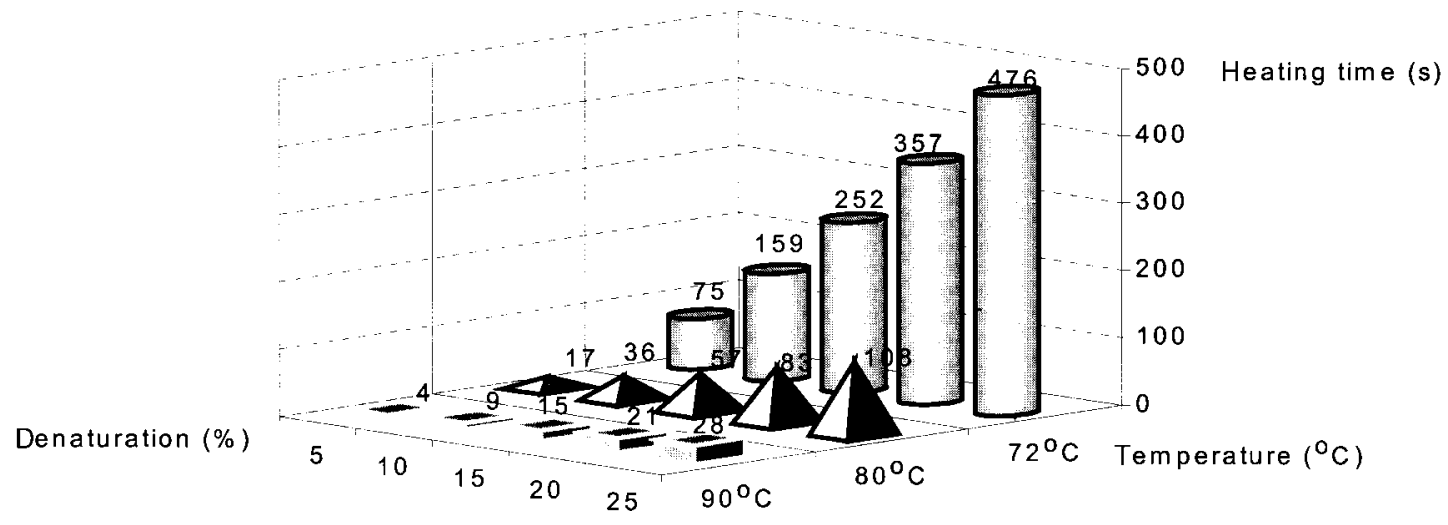

Fig. 1. Heat denaturation of bovine lactoferrin as a function of time and temperature (Kussendrager, 1994). The figure lists the heating times (s) which give either $5,10,15,20$ or $25 \%$ denaturation of $0.1 \%$ bovine lactoferrin in $10 \mathrm{~mm}$ sodium phosphate buffer (pH 6.5) at temperatures of 72 , 80 or $90^{\circ} \mathrm{C}$.

studied in model systems using buffered aqueous solutions or when added to milk.

Abe et al. (1991) investigated the heat stability of bovine apolactoferrin in distilled water adjusted with $\mathrm{HCl}$ or $\mathrm{NaOH}$ to different $\mathrm{pH}$ values. Temperatures were varied from $80^{\circ} \mathrm{C}$ to $120^{\circ} \mathrm{C}$; a fixed heating time of $5 \mathrm{~min}$ was chosen. At neutral and alkaline $\mathrm{pH}(\mathrm{pH}$ 6-10) turbidity and sometimes gel formation occurred, the effect being more pronounced with higher temperatures. Screening involved residual iron binding, reactivity with antiserum, antibacterial activity and HPLC homogeneity. The final conclusion was that heating apolactoferrin at $\mathrm{pH} 4$ for $5 \mathrm{~min}$ at $90^{\circ} \mathrm{C}$ was a pragmatic way for batch sterilization. Preheating at $70^{\circ} \mathrm{C}$ for $3 \mathrm{~min}$ followed by UHT for $2 \mathrm{~s}$ at $130^{\circ} \mathrm{C}$ gave only $3 \%$ loss in residual iron-binding capacity when compared with the unheated sample.

Paulsson et al. (1993) studied the thermal stability of (bovine) apolactoferrin and iron-saturated lactoferrin in relation to the antibacterial activity and/or bacterial interaction. Pasteurization at $72^{\circ} \mathrm{C}$ for $15 \mathrm{~s}$ had no influence when compared to the unheated control; however, UHT treatment $\left(4 \mathrm{~s}, 135^{\circ} \mathrm{C}\right)$ abolished the ability of ironsaturated lactoferrin to bind to bacteria as well as the bacteriostatic activity of apolactoferrin.

Sanchez et al. (1992b) showed first-order reaction kinetics for denaturation of bovine lactoferrin between $72^{\circ} \mathrm{C}$ and $85^{\circ} \mathrm{C}$. Apolactoferrin denatures faster than hololactoferrin; when phosphate buffer was compared to milk, it became clear that the heat-sensitivity of both lactoferrins was higher in the milk matrix. The authors concluded that the standard pasteurization regimes used in the dairy industry had practically no effect on lactoferrin structure. A similar conclusion was drawn by Luf \& Rosner (1997). In a follow-up study Oria et al. (1993) used the interaction of lactoferrin with monocytes to assess the effects of a treatment of $8 \mathrm{~s}$ at $137^{\circ} \mathrm{C}$ on the ability to displace labelled lactoferrin or to stimulate cell proliferation. This heat treatment had only little effect.

In a kinetic approach using differential scanning calorimetry to analyse unfolding of bovine lactoferrin and immunodiffusion for aggregation, Kussendrager (1994) concluded that the thermal stability of lactoferrin is affected by environmental conditions such as $\mathrm{pH}$, salts and (whey) protein, and that, as a consequence, the parameters of the heat-induced denaturation of lactoferrin have to be determined under conditions of the application of interest. Fig. 1 shows the heat denaturation of bovine lactoferrin $(0.1 \%$ in phosphate buffer, $\mathrm{pH} 6.5)$ in function of time at temperatures of 72,80 and $90^{\circ} \mathrm{C}$, respectively (Kussendrager, 1994).

\section{Application examples}

We used an experimental model for shelf-life improvement to investigate whether the iron-scavenging properties of lactoferrin are retained after prolonged processing at about $70^{\circ} \mathrm{C}$ in an industrial environment. We prepared a soy fat powder in our pilot factory with $55 \%$ soy oil, containing unsaturated fatty acids vulnerable to oxidation, $20 \%$ of protein (half caseinate, half whey protein), and $20 \%$ maltodextrin; the residual $5 \%$ consisted of moisture, minerals and other minor components. In order to protect the unsaturated fatty acids against oxidation and as a consequence the powder against development of rancidity and decrease in powder performance and dissolving characteristics, a vitamin based antioxidant mix or bovine lactoferrin were included as well. The rationale behind addition of lactoferrin was that in this way oxidation catalysts like iron and copper ions could be captured and neutralized. The estimated residence time of lactoferrin at $70^{\circ} \mathrm{C}$ during the liquid processing prior to spraydrying was about 30 minutes. After spraydrying the powder was stored at $5^{\circ} \mathrm{C}, 20^{\circ} \mathrm{C}$ and $30^{\circ} \mathrm{C}$ for 12 months and evaluated regularly with respect to peroxide development, an indicator of the protective effects of the antioxidant ingredients; the control contained no antioxidant additions. Fig. 2 shows the peroxide development profile at $30^{\circ} \mathrm{C}$ for the three different powder types. It can be concluded that lactoferrin improved the shelf life of the soy fat powder; compared to the vitamin mix the protective effect is even slightly better. At $20^{\circ} \mathrm{C}$ the performance of both antioxidants was comparable. The control had higher peroxide values at all three temperatures. This example shows the potential of lactoferrin as an antioxidant in food products to 


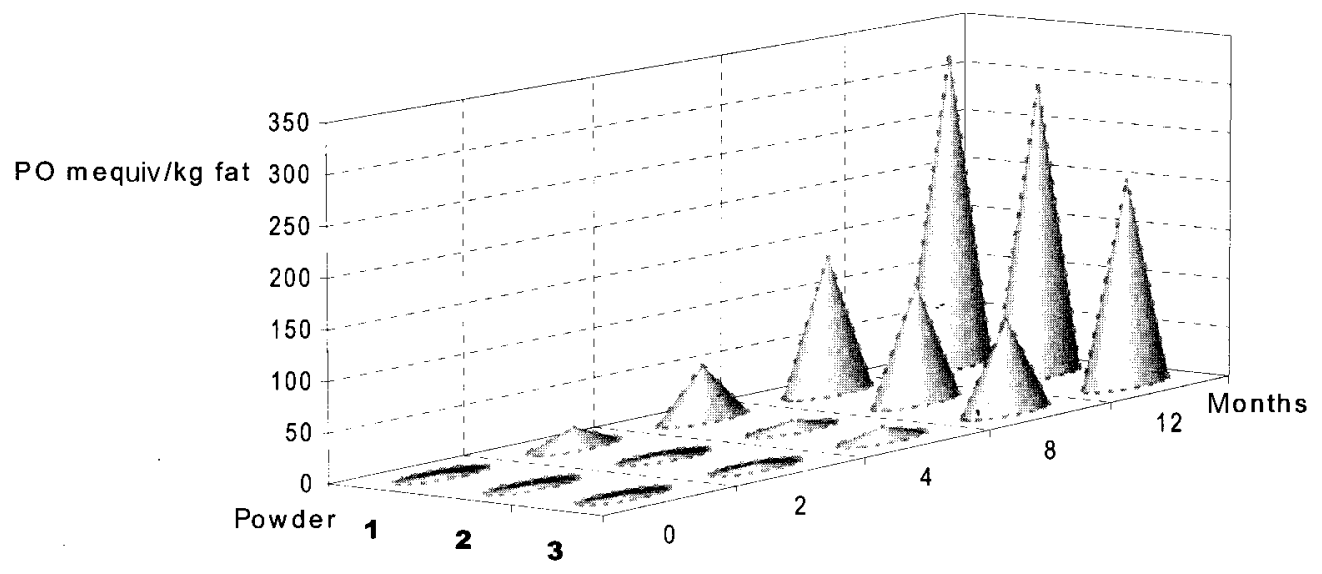

Fig. 2. Lactoferrin as an antioxidant. Powders were stored for up to 12 months at $30^{\circ} \mathrm{C}$; at the indicated time points samples were analysed for peroxides (PO), expressed in mequiv/kg fat. Powder 1 is the control without added antioxidant; powder 2 contains 150 p.p.m. ascorbylpalmitate and 30 p.p.m. dl- $\alpha$-tocopherol; powder 3 contains 100 p.p.m. bovine lactoferrin.

Table 4. Current commercial application of bovine lactoferrin

\begin{tabular}{ll}
\hline Market segment & \multicolumn{1}{c}{ Functionalities described } \\
\hline Milk-based infant formulas & Mimic breast milk, improved resistance against pathogens \\
Health supplements & Aid in iron absorption, e.g. for pregnant women, immune aid \\
Functional food drinks & Increases iron solubility and absorption \\
Cosmetics & Antioxidant \\
Oral care products, chewing gums & Improved oral hygiene \\
Feed supplements & Anti-feline virus in cats \\
\hline
\end{tabular}

increase shelf life. The mechanism by which lactoferrin exerts this antioxidant effect is likely the control of the iron or copper catalysed Fenton reaction, which generates the potent hydroxyl free radical from peroxides (Matsue et al. 1994, 1995). This mechanism is different from the radical quenching effects exerted by antioxidant vitamins like tocopherols. It is not known at present whether antioxidant vitamins and lactoferrin can act synergistically.

Finally Table 4 shows which functionalities of (bovine) lactoferrin are currently highlighted in commercial products.

\section{Conclusion}

Human and bovine lactoferrin are by now fairly well characterized biologically active proteins. Although differences in structural and biochemical properties exist, their bioactivity, as assessed in vitro or in animal models, is quite comparable. Bovine lactoferrin is currently used in commercial products targeting at optimal iron delivery, mimicking human breast milk or boosting the natural defence against infections. Both nutritional and functional use as a natural antioxidant are also foreseen due to lactoferrin's ability to tightly scavenge iron thereby removing an important catalyst for radical formation.

Lactoferrin provides an excellent example of how comparison of the composition of the milk from humans and cows with respect to their function for the newborn, can initiate commercial development and production of a minor milk protein component with broad application possibilities in food and feed.

\section{References}

Abe H, Saito H, Miyakawa H, Tamura Y, Shimamura S, Nagao E \& Tomita M (1991) Heat stability of bovine lactoferrin at acidic pH. Journal of Dairy Science 74, 65-71.

Arnold R, Pruitt KM, Cole MF, Adamson JM \& McGhee JR (1979) Salivary antibacterial mechanisms in immunodefiency. In Saliva and Dental Caries, pp. 449-462 [I Kleinberg, SA Ellison \& ID Mandel, editors]. Washington: Information Retrieval Inc.

Baker EN, Anderson BF, Baker HM, Day CL, Haridas M, Norris GE, Rumball SV, Smith CA \& Thomas DH (1994) Three-dimensional structure of lactoferrin in various functional states. Advances in Experimental Medicine and Biology 357, 112.

Bellamy W, Takase M, Yamauchi K, Wakabayashi H, Kawase K \& Tomita M (1992) Identification of the bactericidal domain of lactoferrin. Biochimica et Biophysica Acta 1121, 130-136.

Bezault J, Bhimani R, Wiprovnick J \& Furmanski P (1994) Human lactoferrin inhibits growth of solid tumors and development of experimental metastases in mice. Cancer Research 54, 2310-2312.

Britigan BE, Serody JS \& Cohen MS (1994) The role of lactoferrin as an anti-inflammatory molecule. Advances in Experimental Medicine and Biology 357, 143-156.

Brodie AH, Ainscough EW, Baker EN, Baker HM, Shongwe MS \& Smith CA (1994) Synergism and substitution in the lactoferrins. Advances in Experimental Medicine and Biology 357, 33-44. 
Coddeville B, Strecker G, Wieruszeski J-M, Vliegenthart JFG, van Halbeek H, Peter-Katalinic J, Egge H \& Spik G (1992) Heterogeneity of bovine lactotransferrin glycans. Characterization of $\alpha$-D-Gal p-(1 $\rightarrow 3)-\beta$-D-Gal- and $\alpha$-NeuAc- $(2 \rightarrow 6)-\beta$ D-GalpNAc- $(1 \rightarrow 4)-\beta$-D-GlcNAc-substituted N-linked glycans. Carbohydrate Research 236, 145-164.

Cohen MS, Mao J, Rasmussen GT, Serody JS \& Britigan BB (1992) Interaction of lactoferrin and lipopolysaccharide (LPS): effects on the antioxidant property of lactoferrin an the ability of LPS to prime human neutrophils for enhanced superoxide formation. Journal of Infectious Diseases 166, 1375-1378.

Dionysius DA \& Milne JM (1997) Antibacterial peptides of bovine lactoferrin: purification and characterization. Journal of Dairy Science 80, 667-674.

Elass-Rochard E, Roseanu A, Legrand D, Salmon V, Motas C, Montreuil J \& Spik G (1995) Lactoferrin-lipopolysaccharide interaction: involvement of the 28-34 loop region of human lactoferrin in the high-affinity binding to Escherichia coli 055B5 lipopolysaccharide. Biochemical Journal 312, 839-845.

Faber RH, Anderson BF, Baker HM, Bland T, Day CL, Nicholson H, Shewry S, Tweedie JW \& Baker EN (1997) Altered domain closure and iron binding in lactoferrin mutants. In Lactoferrin: Interactions and Biological Functions, pp. 2538 [TW Hutchens \& B Lönnerdal, editors]. New Jersey: Humana Press.

Hambraeus L \& Lönnerdal B (1994) The physiological role of lactoferrin. In IDF Bulletin: Indigenous Antimicrobial Agents of Milk: Recent Developments (Uppsala 1993, S.I.9404), pp. 97107.

Haridas M, Anderson BF \& Baker EN (1995) Structure of human diferric lactoferrin refined at $2 \cdot 2 \AA$ resolution. Acta Crystallographia D51, 629-646.

Harmsen MC, Swart PJ, DeBéthune M-P, Pauwels R, De Clercq E, Hauw The T \& Meijer DKF (1995) Antiviral effects of plasma and milk proteins: lactoferrin shows potent activity against both human immunodeficiency virus and human cytomegalovirus replication in vitro. Journal of Infectious Diseases 172, 380388.

Harrington JP, Stuart J \& Jones A (1987) Unfolding of iron and copper complexes of human lactoferrin and transferrin. International Journal of Biochemistry 19, 1001-1008.

Hoek KS, Milne JM, Grieve PA, Dionysius DA \& Smith R (1997) Antibacterial activity of bovine lactoferrin derived peptides. Antimicrobial Agents and Chemotherapy 41, 54-59.

Hurley WL, Grieve RCJ, Magura CE, Hegarty HM \& Zou S (1993) Electrophoretic comparisons of lactoferrin from bovine mammary secretions, milk neutrophils, and human milk. Journal of Dairy Science 76, 377-387.

Hutchens TW \& Lönnerdal B (editors) (1997) Lactoferrin: Interactions and Biological Functions, New Jersey: Humana Press.

Hutchens TW, Rumball SV \& Lönnerdal B (editors) (1994) Lactoferrin: Structure and Function. In Advances in Experimental Medicine and Biology vol. 357, New York: Plenum Press.

Inoue M, Yamada J, Kitamura N, Shimazaki K-I, Andren A \& Yamashita $T$ (1993) Immunohistochemical localization of lactoferrin in bovine exocrine glands. Tissue and Cell 25, 791-797.

Kang JH, Lee MK, Kim KL \& Hahm K-S (1996) Structurebiological activity relationships of 11-residue highly basic peptide segments of bovine lactoferrin. International Journal of Peptide and Protein Research 48, 357-363.

Kawakami H, Dosako S \& Nakajima I (1993) Effect of lactoferrin on iron solubility under neutral conditions. Bioscience Biotechnology Biochemistry 57, 1376-1377.

Kawakami H, Hiratsuka M \& Dosako S (1988) Effects of iron- saturated lactoferrin on iron absorption. Agricultural and Biological Chemistry 52, 903-908.

Korhonen H (1977) Antimicrobial factors in bovine colostrum. Journal of the Scientific Agricultural Society of Finland 49, 434-447.

Kussendrager K (1994) Effects of heat treatment on structure and iron-binding capacity of bovine lactoferrin. In IDF Bulletin: Indigenous Antimicrobial Agents of Milk: Recent Developments (Uppsala 1993, S.I.9404), pp. 133-146.

Legrand D, Mazurier J, Colavizza D, Montreuil J \& Spik G (1990) Properties of the iron-binding site of the N-terminal lobe of human and bovine lactotransferrins. Biochemical Journal 266, 575-581.

Legrand D, VanBerkel PHC, Salmon V, VanVeen HA, Slomianny M-C, Nuijens JH \& Spik G (1997) The N-terminal $\mathrm{Arg}^{2}, \mathrm{Arg}^{3}$ and $\mathrm{Arg}^{4}$ of human lactoferrin interact with sulphated molecules but not with the receptor present on Jurkat human lymphoblastic cells. Biochemical Journal 327, 841-846.

Levay PF \& Viljoen M (1995) Lactoferrin: a general review. Haematologica 80, 252-267.

Lönnerdal B \& Iyer S (1995) Lactoferrin: molecular structure and biological function. Annual Review of Nutrition 15, 93-110.

Luf W \& Rosner E (1997) Zur Thermostabilität von Lactoferrin in Kuhmilch. Wiener Tieraertzliche Monatsschrift 84, 70-73.

Magnusson JS, Henry JH, Yip T-T \& Hutchens TW (1990) Structural homology of human, bovine, and porcine milk lactoferrins: evidence for shared antigenic determinants. Pediatric Research 28, 176-181.

Marchetti M, Longhi C, Conte MP, Pisani S, Valenti P \& Seganti L (1996) Lactoferrin inhibits herpes simplex virus type 1 adsorption to Vero cells. Antiviral Research 29, 221-231.

Matsue M, Matsuyama J \& Kiyosawa I (1995) Interaction of lactoferrin with ascorbate and the relationship with bleomycindependent DNA damage. Bioscience Biotechnology Biochemistry 59, 358-362.

Matsue M, Tomita S, Nyui S, Matayuma J \& Kiyosawa I (1994) Suppressive effects of lactoferrin on bleomycin-dependent DNA damage by the iron ion and ascorbate. Bioscience Biotechnology Biochemistry 58, 67-71.

Mattsby-Baltzer I, Roseanu C, Motas C, Elverfors J, Engberg I \& Hanson LA (1996) Lactoferrin or a fragment therof inhibits the endotoxin-induced interleukin-6 response in human monocytic cells. Pediatric Research 40, 257-262.

Mikogami T, Marianne T \& Spik G (1995) Effect of intracellular iron depletion by picolinic acid on expression of the lactoferrin receptor in the human colon carcinoma cell subclone HT29-18C1. Biochemical Journal 308, 391-397.

Moore SA, Anderson BF, Groom CR, Haridas M \& Baker EN (1997) Three-dimensional structure of diferric bovine lactoferrin at $2.8 \AA$ resolution. Journal of Molecular Biology 274, 222 236.

Naidu AS \& Arnold RR (1997) Influence of lactoferrin on hostmicrobe interactions. In Lactoferrin: Interactions and Biological Functions, pp. 259-275 [TW Hutchens \& B Lönnerdal, editors]. New Jersey: Humana Press.

Oria R, Ismael M, Sanchez L, Calvo M \& Brock J (1993) Effect of heat treatment and other milk proteins on the interaction of lactoferrin with monocytes. Journal of Dairy Research 60, 363-369.

Paulsson MA, Svensson U, Kishore AR \& Naidu AS (1993) Thermal behaviour of bovine lactoferrin in water and its relation to bacterial interaction and antibacterial activity. Journal of Dairy Science 76, 3711-3720.

Pierce A, Colavizza D, Benaissa M, Maes P, Tartra A, Montreuil J \& Spik G (1991) Molecular cloning and sequence analysis of bovine lactoferrin. European Journal of Biochemistry 196, 177-184. 
Reiter B (1985) The biological significance of the nonimmunoglobulin protective proteins in milk. Developments in Dairy Chemistry 3, 281-336.

Renner E, Schaafsma G \& Scott KJ (1989) Micronutrients in milk. In Micronutrients in Milk and Milk-based Food Products, pp. 1-70 [E Renner, editor]. New York: Elsevier Applied Science.

Sanchez L, Calvo M \& Brock JH (1992a) Biological role of lactoferrin. Archives of Disease in Childhood 67, 657-661.

Sanchez L, Peiro JM, Castillo H, Perez MD, Ena JM \& Calvo M (1992b) Kinetic parameters for denaturation of bovine milk lactoferrin. Journal of Food Science 57, 873-879.

Schanbacher FL, Talhouk RS \& Murray FA (1997) Biology and origin of bioactive peptides in milk. Livestock Production Science 50, 105-123.

Sekine K, Watanabe E, Nakamura J, Takasuka N, Kim DY, Asamoto M, Krutovskikh V, Baba-Toriyama H, Ota T, Moore MA, Masuda M, Sugimoto H, Nishino H, Kazikoe T \& Tsuda H (1997) Inhibition of azoxymethane-initiated colon tumor by bovine lactoferrin adminsitration in F344 rats. Japanese Journal of Cancer Research 88, 523-526.

Shimazaki K-I, Kawaguchi A, Sato T, Ueda Y, Tomimura T \& Shimamura S (1993) Analysis of human and bovine milk lactoferrins by rotofor and chromatofocussing. International Journal of Biochemistry 25, 1653-1658.

Shimazaki K-I, Tsuda H, Tomita M, Kuwata T \& Perraudin J-P (editors) (2000) Lactoferrin: Structure, Function and Applications, Exerpta Medica International Congress Series 1195. Amsterdam: Elsevier.

Shimizu K, Matsuzawa H, Okada K, Tazume S, Dosako S, Kawasaki Y, Hashimoto K \& Koga Y (1996) Lactoferrinmediated protection of the host from murine cytomegalovirus infection by a T-cell dependent augmentation of natural killer cell activity. Archives of Virology 141, 1875-1889.

Spik G, Coddeville B, Mazurier J, Bourne Y, Cambillaut C \& Montreuil J (1994) Primary and three-dimensional structure of lactotransferrin (lactoferrin) glycans. Advances in Experimental Medicine and Biology 357, 21-32.
Spik G, Legrand D, Mazurier J, Pierce A \& Perraudin J-P (editors) (1998) Advances in lactoferrin research. In Advances in Experimental Medicine and Biology vol. 443, New York: Plenum Press.

Tomita M, Takse M, Wakabayashi H \& Bellamy W (1994) Antimicrobial peptides of lactoferrin. Advances in Experimental Medicine and Biology 357, 209-218.

VanBerkel PHC (1998) Structure-function Studies of Human Lactoferrin Thesis, University of Leiden, The Netherlands, pp. 95-100

VanBerkel PHC, Geerts ME, VanVeen HA, Kooiman PM, Pieper FR, DeBoer H \& Nuijens JH (1995) Glycosylated and unglycosylated human lactoferrins both bind iron and show identical affinities towards lysozyme and bacterial lipopolysaccharide, but differ in their susceptibilities towards tryptic proteolysis. Biochemical Journal 312, 107-114.

VanBerkel PHC, Geerts M, VanVeen HA, Mericskay M, DeBoer H \& Nuijens JH (1997) N-terminal stretch $\mathrm{Arg}^{2}$, $\mathrm{Arg}^{3}, \mathrm{Arg}^{4}$ and $\mathrm{Arg}^{5}$ of human lactoferrin is essential for binding to heparin, bacterial lipopolysaccharide, human lysozyme and DNA. Biochemical Journal 328, 141-151.

Ward PP, Zhou X \& Conneely OM (1996) Cooperative interactions between the amino- and carboxyl-terminal lobes contribute to the unique iron-binding stability of lactoferrin. Journal of Biological Chemistry 22, 12790-12794.

Yi M, Kaneko S, Yu DY \& Murakami S (1997) Hepatitis C virus envelope proteins bind lactoferrin. Journal of Virology 71, 5997-6002.

Yoo Y-C, Watanane S, Watanabe R, Hata K, Shimazaki K-I \& Azuma I (1997) Bovine lactoferrin and lactoferricin, a peptide derived from bovine lactoferrin, inhibit tumor metastasis in mice. Japanese Journal of Cancer Research 88, 184-190.

Zimecki M, Mazurier J, Machnicki M, Wieczorek Z, Montreuil J \& Spik G (1991) Immunostimulatory activity of lactoferrin and maturation of CD4-, CD8-murine thymocytes. Immunology Letters 30, 119-123. 